\title{
Increased urinary albumin excretion and its associations in the WHO Multinational Study of Vascular Disease in Diabetes
}

\author{
P. H. Bennett ${ }^{1}$, E.T.Lee ${ }^{2}$, M.Lu ${ }^{2}$, H.Keen ${ }^{3}$, J.H.Fuller ${ }^{4}$ and the WHO Multinational Study Group* \\ ${ }^{1}$ Phoenix Epidemiology and Clinical Research Branch, NIDDK, Phoenix, Arizona, USA \\ ${ }^{2}$ Centre for American Indian Health Research and Department of Biostatistics and Epidemiology, College of Public Health, \\ University of Oklahoma Health Sciences Center, Oklahoma City, USA \\ ${ }^{3}$ Unit for Metabolic Medicine, Guy's Hospital, London, UK \\ ${ }^{4}$ EURODIAB, Department of Epidemiology and Public Health, University College, London, UK
}

\section{Abstract}

Aim/hypothesis. We aimed to determine variations in the prevalence of increased urinary albumin excretion, associated risk factors and complications in patients with diabetes participating in the WHO Multinational Study of Vascular Disease in Diabetes follow-up.

Methods. Urinary albumin to urinary creatinine ratios were measured centrally in 2033 of the 2550 $(79.7 \%)$ re-examined patients from eight centres in seven countries and the frequency of microalbuminuria and macroalbuminuria and their associations with risk factors and complications were examined. Results. Macroalbuminuria prevalence (overall $15.6 \%$ ) varied tenfold (3-37\%) among centres, was higher in American Indian and Asian centres and not clearly related to type of diabetes. Microalbuminuria (overall $19.7 \%$ ) varied less (12-31 \% ). Increased albumin excretion was related overall to baseline fasting plasma glucose in the pooled group in whom it was measured and to increased arterial pressure, insulin use, coronary heart disease, lower extremity amputation, retinopathy and stroke in most centres.

Conclusion/interpretation. Centres varied widely in the prevalence of increased albumin excretion but associations with risk factors and vascular complications were generally similar in most centres and in both major types of diabetes with ethnic and genetic differences probably contributing. [Diabetologia (2001) 44 [Suppl 2]: S 37-S 45]

Keywords Albuminuria, Prevalence, Vascular complications, Risk factors, Multinational study.
Diabetic nephropathy is the most common cause of end-stage renal disease in the United States [1,2] accounting for $41.8 \%$ of new cases in 1997 . Its associations with other vascular complications of diabetes result in significant morbidity and mortality [3-6]. Small increases in urinary albumin excretion (UAE) predict the development of clinical pro-

\footnotetext{
* See reference 15 for list of investigators

Corresponding author: Elisa T.Lee, PhD, College of Public Health, University of Oklahoma Sciences Center, P.O.Box 26901, Oklahoma City, OK 73190, USA

Abbreviations: WHO MSVDD, World Health Organization Multinational Study of Vascular Disease in Diabetes; UAE, urinary albumin excretion; UAC, urinary albumin to urinary creatine ratio; OR, odds ratio; SBP, systolic blood pressure; DBP, diastolic blood pressure.
}

teinuria and renal failure [7-9]. Its detection allows interventions which could slow or reverse this progression [10-13].

The prevalence of increased UAE (microalbuminuria and macroalbuminuria) was determined in eight of the ten centres participating in the follow-up of the WHO Multinational Study of Vascular Disease in Diabetes (WHO MSVDD) and its associations with risk factors and diabetic complications assessed for each.

\section{Subjects and methods}

Of the ten follow-up centres of the WHO MSVDD [14], urine samples were not available from most patients in Zagreb and Switzerland who thus were excluded from the analysis. Among the remaining eight centres, $2033(79.7 \%)$ of the 2550 patients 
Table 1. Prevalence (\%) of increased albumin excretion by centre

\begin{tabular}{|c|c|c|c|}
\hline \multirow[b]{2}{*}{ Centre } & \multirow{2}{*}{$\begin{array}{l}\text { No of subjects } \\
\text { examined }\end{array}$} & \multicolumn{2}{|l|}{ UAC ratio } \\
\hline & & $\begin{array}{l}30-299 \mathrm{mg} / \mathrm{g} \\
\%(n)\end{array}$ & $\begin{array}{l}\geq 300 \mathrm{mg} / \mathrm{g} \\
\%(n)\end{array}$ \\
\hline London & 330 & $12.1(40)$ & $3.0(10)$ \\
\hline Warsaw & 186 & $18.8(35)$ & 9.7 (18) \\
\hline Berlin & 214 & $14.5(31)$ & 7.9 (17) \\
\hline Hong Kong & 267 & $20.6(55)$ & $20.6(55)$ \\
\hline Tokyo & 257 & $21.0(54)$ & $9.0(23)$ \\
\hline Havana & 303 & $13.5(41)$ & $8.6(26)$ \\
\hline Oklahoma & 306 & 29.7 (91) & $36.9(113)$ \\
\hline Arizona & 170 & $31.2(53)$ & $32.9(56)$ \\
\hline Overall & 2033 & $19.7(400)$ & $15.6(318)$ \\
\hline
\end{tabular}

re-examined at follow-up had measurements of urinary albumin and urinary creatinine on samples collected at the examination visit. All measurements were made by the central laboratory in Phoenix, Arizona in the United States by methods described elsewhere [15].

The urinary albumin to creatinine ratio (UAC) was used to estimate albumin excretion $[16,17]$. Increased UAE was defined as a UAC ratio of $30 \mathrm{mg} / \mathrm{g}$ or more and was subdivided into microalbuminuria (UAC ratio 31-299 mg/g) and macroalbuminuria (UAC ratio $\geq 300 \mathrm{mg} / \mathrm{g}$ ). "Clinical proteinuria" was based on local tests using the Albustix method.

Statistical associations of UAE were explored with factors including sex, age, age at diagnosis of diabetes, duration of diabetes, type of diabetes, treatment for diabetes, systolic, diastolic and mean (1/3 systolic $+2 / 3$ diastolic) arterial pressure, hypertension status, body mass index (BMI - quartiles by centre), and current smoking status. Fasting plasma glucose was measured at baseline in only a subset of the centres; this yielded 1311 patients with follow-up UAE estimations and these were pooled for analysis. . Associations with vascular complications as defined [15] included coronary heart disease, stroke, lower-extremity amputation, and retinopathy.

Standard statistical methods [15] and the natural logarithm of the UAC ratio for Pearson correlation coefficients were used. Stratified analysis used the Mantel and Haenszel statistic [19]. Odds ratios with adjustment for sex, age and duration of diabetes used SAS [18] and BMDP [20] in multivariate step-

Fig. 1. Prevalence (\%) of increased albumin excretion by type of diabetes, sex and centre. $\square>=300 \mathrm{mg} / \mathrm{g} ; \square 30-299 \mathrm{mg} / \mathrm{g}$

Men

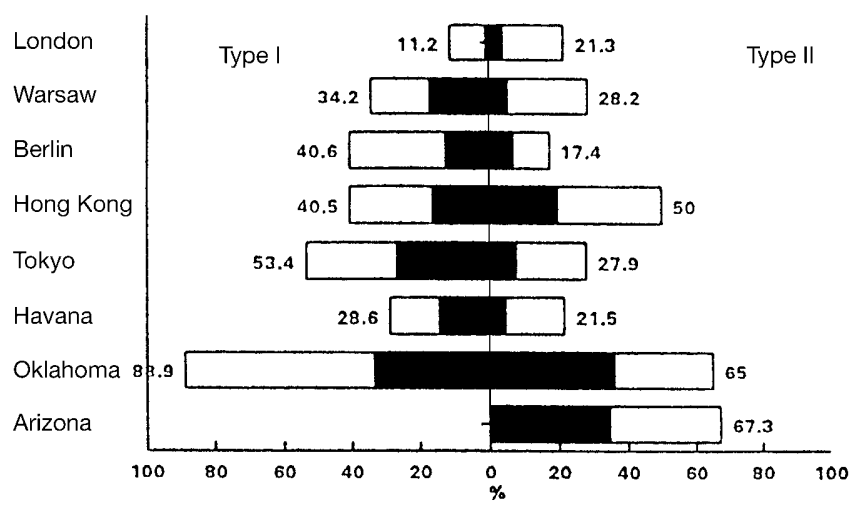

wise linear logistic regression analyses to identify factors significantly related to increased UAE.

\section{Results}

The prevalence of increased UAE at follow-up by centre is shown in Table 1. Macroalbuminuria rates varied tenfold, being highest in Oklahoma and Arizona and lowest in London and were little affected after stratification by sex and type of diabetes (Fig.1). A trend to higher prevalence of increased albumin excretion in Type I (insulin-dependent) than Type II (non-insulin-dependent) diabetes mellitus was not apparent in London or Hong Kong. Of patients with UAC ratios of $\geq 300 \mathrm{mg} / \mathrm{g}$ or more, $91 \%$ were Albustix positive $(\geq 1+)$ compared with $0.7 \%$ of the patients with UAC ratios of less than $30 \mathrm{mg} / \mathrm{g}$ and $19.3 \%$ with UAC ratios of 30 to $299 \mathrm{mg} / \mathrm{g}$.

In the pooled sample of 1311 patients, baseline fasting plasma glucose concentrations significantly correlated with follow-up urinary albumin creatinine ratio (log transformed values $r=0.25 p<0.0001$ ). This is mainly evident in the positive association of baseline glucose (in tertiles) with follow-up macroalbuminuria (urinary ACR > 299) (Table 2).

Within centres, rates of increased UAE differed little with sex $(p>0.05)$ or age except in Arizona $(p<0.05)$ but were higher with diabetes diagnosis before the age of 30 in Oklahoma and Berlin $(p<0.05)$ and for macroalbuminuria in Warsaw and Berlin $(p<0.05)$. Macroalbuminuria prevalence increased suggestively with duration of diabetes in all centres except London (Fig.2). Prevalence of increased UAE was higher in patients receiving insulin than in those on other treatments $(p<0.05)$ except in Havana and London.

The prevalence of increased UAE was greater in those with higher systolic blood pressure (SBP) at all centres $(p<0.05)$ and suggestively greater in those with higher diastolic blood pressure (DBP) in six of the eight centres (Fig. 3). Patients with categorical hypertension had a higher prevalence of increased

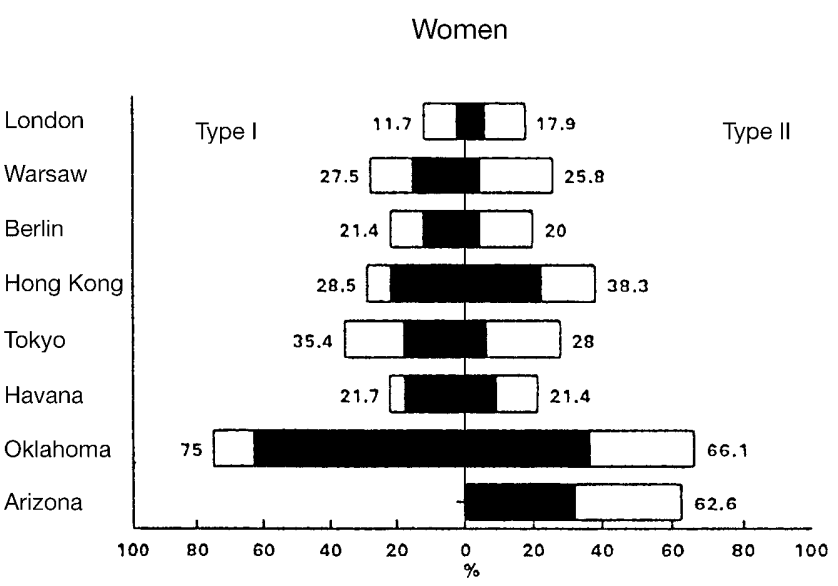




\section{Albuminuria by duration of diabetes}

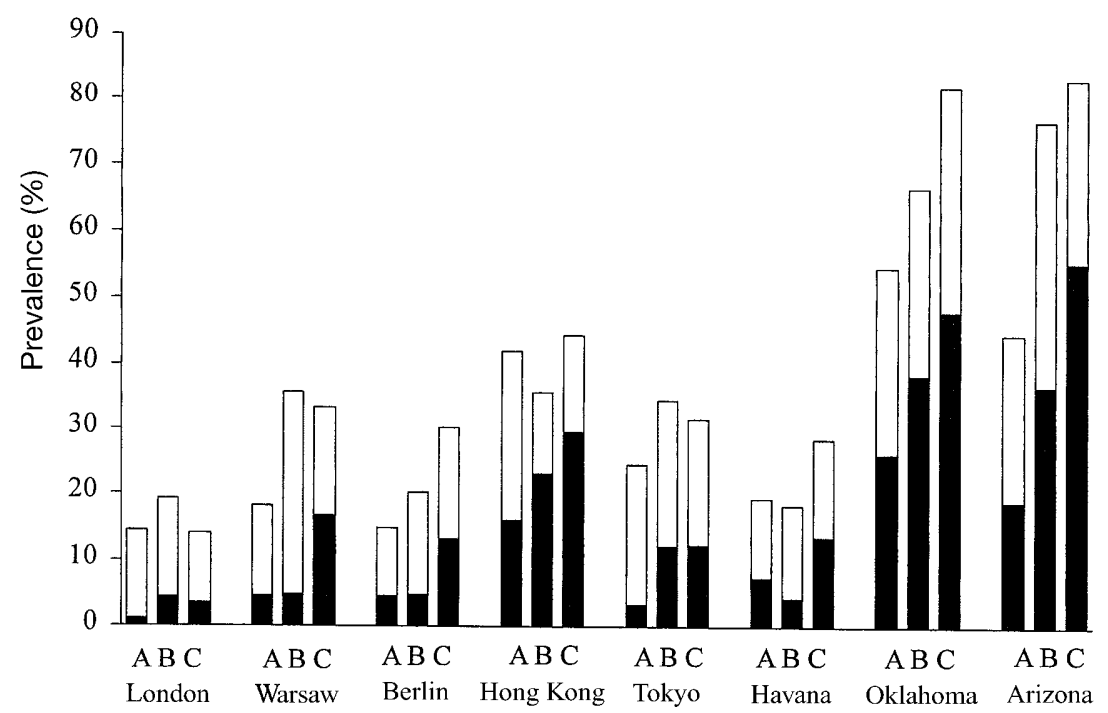

Fig. 2. Prevalence (\%) of increased UAE by duration of diabetes $(\mathrm{A},<15 ; \mathrm{B}, \quad 15-19 ; \quad \mathrm{C},>=20$ years $)$ and centre. - $>=300 \mathrm{mg} / \mathrm{g} ; \square 30-299 \mathrm{mg} / \mathrm{g}$

UAE than those without $(p<0.05)$, not significant in the American Indian cohorts (Fig. 4). Current smoking status was positively associated with UAE in Tokyo but negatively in Oklahoma $(p<0.05)$. BMI was significantly related to UAE only in Warsaw and London ( $p<0.05$, Fig. 5$)$.

Mean SBP was higher in patients with increased UAE than in those with normal excretion in all centres $(p<0.05)$ except Arizona and mean DBP was higher $(p<0.05)$ in five of the eight. Compared with normoalbuminuric patients, those with increased UAE had higher mean plasma creatinine concentrations at all centres except Warsaw $(p<0.05)$ and showed significant differences in age, age at diagnosis, duration of diabetes and BMI in one or more centre.
Log UAC ratio correlated positively with SBP at all centres $(r=0.22$ to $0.36, p<0.01)$, with DBP in most $(r=0.18$ to $0.20, p<0.05)$ and with plasma creatinine at all centres $(r=0.20$ to $0.39, p<0.01)$ except Warsaw $(p>0.05)$. It correlated positively with diabetes duration in 5 of the 8 centres $(r=0.16$ to 0.24 , $p<0.05)$ and negatively with age at diagnosis in 3 $(r=-0.15$ to $-0.18, p<0.05)$. Log UAC correlated with age in London and Hong Kong $(r=0.15$ and 0.16 , respectively, $p<0.05)$ and positively with BMI in London $(r=0.17, p<0.01)$ but negatively in Havana $(r=-0.15, p<0.05)$.

Odds ratios (OR) for increased UAE adjusted for age, sex and duration (Table 3$)$ were raised $(p<0.05)$ for higher SBP at all centres except Arizona, for higher DBP and for insulin treatment compared with other treatments in two centres each. BMI and cigarette smoking were associated with increased UAE in London and Tokyo respectively $(p<0.05)$.

After stratification for type of diabetes (Fig. 6), association of increased UAE with SBP persisted sug-

Table 2. Distribution of Follow-up Urinary Albumin Creatinine (UAC) Ratio by Tertile of Baseline Fasting Plasma Glucose

\begin{tabular}{|c|c|c|c|c|c|}
\hline \multirow{2}{*}{$\begin{array}{l}\text { UAC ratio } \\
(\mathrm{mg} / \mathrm{g})\end{array}$} & & \multicolumn{3}{|c|}{ Fasting plasma glucose tertile $(\mathrm{mmol} / \mathrm{l})$} & \multirow[t]{2}{*}{ Total } \\
\hline & & $\begin{array}{l}1 \\
(<7.3 \mathrm{mmol} / \mathrm{l})\end{array}$ & $\begin{array}{l}2 \\
(7.3-11.7 \mathrm{mmol} / \mathrm{l})\end{array}$ & $\begin{array}{l}3 \\
(>11.7 \mathrm{mmol} / \mathrm{l})\end{array}$ & \\
\hline$<30$ & $\begin{array}{l}n \\
\%\end{array}$ & $\begin{array}{l}328 \\
74.4\end{array}$ & $\begin{array}{r}272 \\
62.5\end{array}$ & $\begin{array}{l}225 \\
51.7\end{array}$ & $\begin{array}{l}825 \\
62.9\end{array}$ \\
\hline $30-299$ & $\begin{array}{l}n \\
\%\end{array}$ & $\begin{array}{l}71 \\
16.1\end{array}$ & $\begin{array}{l}98 \\
22.5\end{array}$ & $\begin{array}{l}98 \\
22,5\end{array}$ & $\begin{array}{l}267 \\
20.4\end{array}$ \\
\hline Total & $\begin{array}{l}n \\
\%\end{array}$ & $\begin{array}{l}441 \\
33.6\end{array}$ & $\begin{array}{l}435 \\
33.2\end{array}$ & $\begin{array}{l}435 \\
33.2\end{array}$ & $\begin{array}{r}1311 \\
100\end{array}$ \\
\hline
\end{tabular}

Chi-Square $59.5 p<0.001$ 


\section{Albuminuria by diastolic blood pressure}

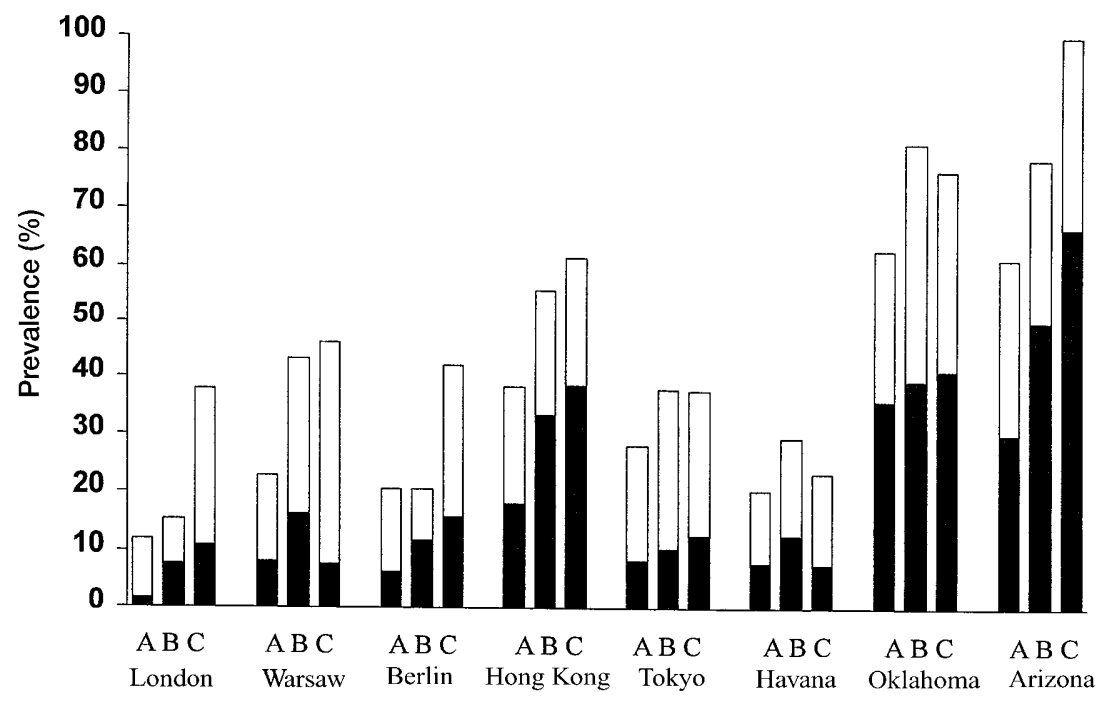

Fig. 3. Prevalence (\%) of increased UAE by diastolic blood pressure (A, <90; B, 90-94; C, > = 95 $\mathrm{mmHg}$ ) and centre. $\square>=300 \mathrm{mg} / \mathrm{g} ; \square 30-299 \mathrm{mg} / \mathrm{g}$

gestively in Type II diabetes in seven of the eight centres and with DBP in five centres. Smoking was positively associated with increased UAE in Tokyo, negatively in Oklahoma $(p<0.05)$ and not associated in other centres (Fig.7). Correlations between arterial

Fig. 4. Prevalence (\%) of increased UAE by hypertension status (no, yes) and centre. $\square>300 \mathrm{mg} / \mathrm{g} ; \square 30-299 \mathrm{mg} / \mathrm{g}$ pressure and UAE were present but less apparent in patients with Type I diabetes. Smoking was not significantly associated in any centre.

The prevalence of coronary heart disease was higher in patients with increased UAE than in those with normoalbuminuria at all centres (Table 4), significantly in London, Hong Kong, Oklahoma, and Arizona $(p<0.05)$. The prevalence of stroke was significant in Berlin, Hong Kong, Oklahoma and Arizona $(p<0.05)$. Lower-extremity amputation rates were also higher in patients with increased UAE at all centres except London, but significant only in the American Indian centres $(p<0.05)$. The prevalence of retinopathy was associated with increased UAE in all centres except Hong Kong and Arizona.

\section{Albuminuria by hypertension}

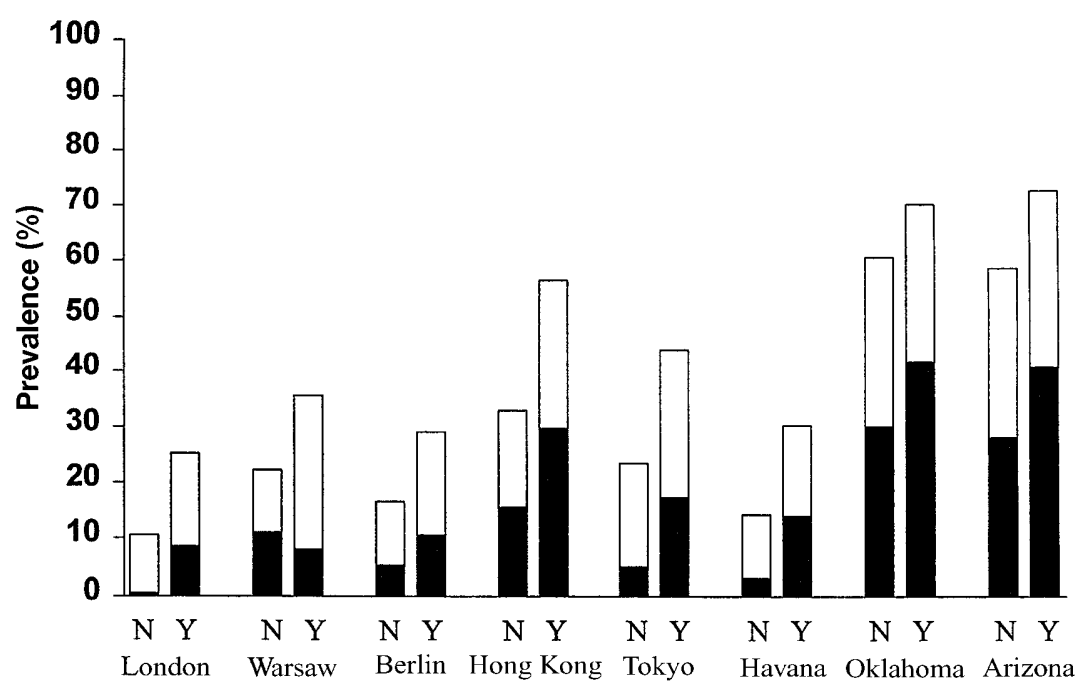




\section{Albumin to creatinine ratio by BMI}

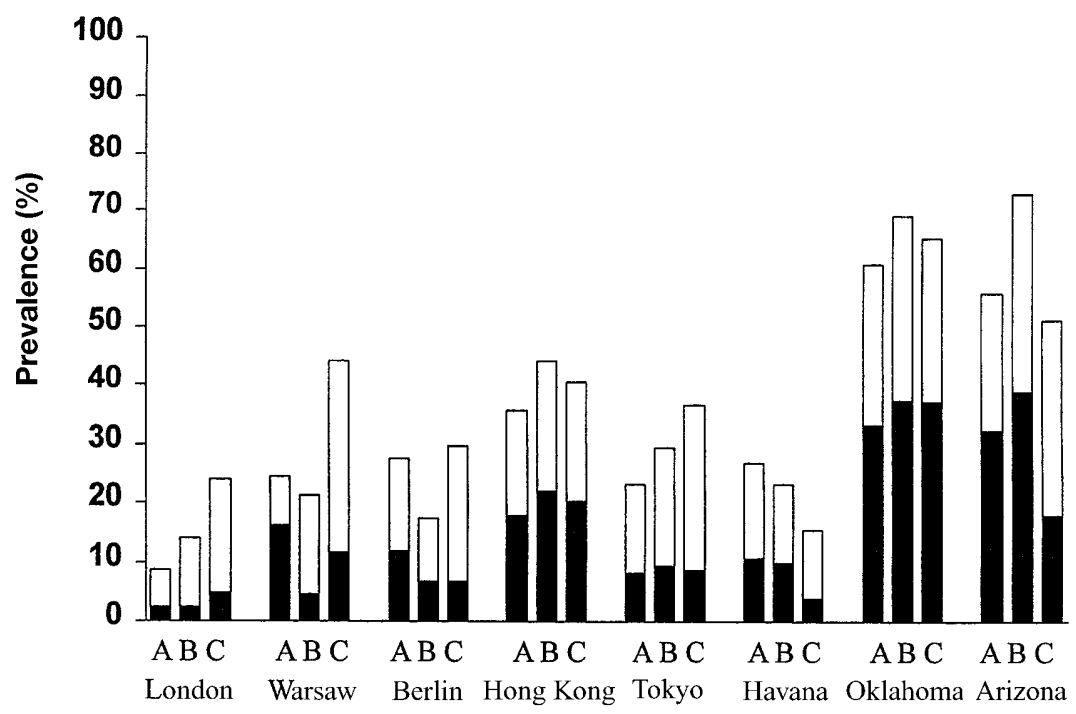

Fig. 5. Prevalence (\%) of increased UAE by BMI (A, Q1; B, Q2-Q3; C, Q4) and centre. $\square>=300 \mathrm{mg} / \mathrm{g} ; \square$ 30-299 mg/g

In stepwise linear logistic regression analyses (Table 5), mean blood pressure was independently associated with increased UAE in all centres $(p<0.05)$ except London $(p<0.10)$. Retinopathy was associated at all centres $(p<0.05)$ except Warsaw, Hong Kong and Arizona and treatment with insulin was related in Berlin, Hong Kong, Tokyo and Oklahoma $(p<0.05)$. Diabetes duration was significantly associated in Oklahoma and Arizona, and coronary heart disease in London, Hong Kong and Arizona $(p<0.05)$. An association with current smoking emerged only in Tokyo $(p<0.05)$ and with BMI only in London and Warsaw $(p<0.05)$. Type of diabetes, sex and age were not associated in any centre $(p>0.05)$.
With macroalbuminuria as a dependent variable (Table 6), as with microalbuminuria, mean blood pressure was associated in all centres except Oklahoma. Presence of retinopathy was associated with macroalbuminuria in four centres as was insulin use. In Warsaw and Havana, patients with Type I diabetes had a higher prevalence of macroalbuminuria than those with Type II diabetes. An association with smoking was significant only in Tokyo.

When patients were classified into three broad ethnic groups for multivariate analysis, the American Indian group (Oklahoma and Arizona) had a significantly higher prevalence of increased UAE than either the European or the Havana group $(\mathrm{OR}=8.7$, $95 \% \mathrm{CI}=6.3-12.1$ ), or the Asian group (Japan and Tokyo OR $=3.4,95 \% \mathrm{CI}=2.3-5.2$ ) with the Asian group also exceeding the European and Havana group $(\mathrm{OR}=3.0,95 \% \mathrm{CI}=2.2-4.0)$.

Table 3. Odds ratio (95\% confidence interval) of variables associated with increased albumin excretion (UAC ratio $\geq 30 \mathrm{mg} / \mathrm{g})$ adjusted for sex, age, and duration of diabetes by centre

\begin{tabular}{|c|c|c|c|c|c|c|c|c|}
\hline Variables & London & Warsaw & Berlin & Hong Kong & Tokyo & Havana & Oklahoma & Arizona \\
\hline $\begin{array}{l}\text { Systolic blood pressure } \\
\text { (per } 10 \mathrm{mmHg} \text { change) }\end{array}$ & $\begin{array}{l}1.27^{*} \\
(1.09-1.47)^{\mathrm{a}}\end{array}$ & $\begin{array}{l}1.28 * \\
(1.10-1.49)\end{array}$ & $\begin{array}{l}1.44 * \\
(1.21-1.70)\end{array}$ & $\begin{array}{l}1.26^{*} \\
(1.12-1.42)\end{array}$ & $\begin{array}{l}1.28 * \\
(1.10-1.48)\end{array}$ & $\begin{array}{l}1.16^{*} \\
(1.04-1.28)\end{array}$ & $\begin{array}{l}1.21 * \\
(1.07-1.36)\end{array}$ & $\begin{array}{l}1.13 \\
(0.96-1.34)\end{array}$ \\
\hline $\begin{array}{l}\text { Diastolic blood pressure } \\
\text { (per } 10 \mathrm{mmHg} \text { change) }\end{array}$ & $\begin{array}{l}1.43^{*} \\
(1.10-1.87)\end{array}$ & $\begin{array}{l}1.71 * \\
(1.19-2.45)\end{array}$ & $\begin{array}{l}1.32 \\
(0.97-1.80)\end{array}$ & $\begin{array}{l}1.34 * * \\
(1.06-1.70)\end{array}$ & $\begin{array}{l}1.39 * \\
(1.08-1.77)\end{array}$ & $\begin{array}{l}1.16 \\
(0.96-1.40)\end{array}$ & $\begin{array}{l}1.32 * * \\
(1.04-1.68)\end{array}$ & $\begin{array}{l}1.59^{*} \\
(1.15-2.21)\end{array}$ \\
\hline $\begin{array}{l}\text { BMI } \\
\text { (per } \mathrm{kg} / \mathrm{m}^{2} \text { quartile) }\end{array}$ & $\begin{array}{l}1.15^{\#} \\
(1.07-1.24)\end{array}$ & $\begin{array}{l}1.11 * \\
(1.04-1.20)\end{array}$ & $\begin{array}{l}1.07 \\
(0.98-1.18)\end{array}$ & $\begin{array}{l}0.99 \\
(0.92-1.07)\end{array}$ & $\begin{array}{l}1.10 \\
(0.99-1.21)\end{array}$ & $\begin{array}{l}0.98 \\
(0.93-1.04)\end{array}$ & $\begin{array}{l}1.02 \\
(0.97-1.06)\end{array}$ & $\begin{array}{l}1.00 \\
(0.94-1.07)\end{array}$ \\
\hline $\begin{array}{l}\text { Insulin use } \\
\text { (0-no,1-yes) }\end{array}$ & $\begin{array}{l}0.72 \\
(0.34-1.53)\end{array}$ & $\begin{array}{l}1.64 \\
(0.69-3.89)\end{array}$ & $\begin{array}{l}3.46^{*} \\
(1.41-8.50)\end{array}$ & $\begin{array}{l}1.89 * * \\
(1.10-3.27)\end{array}$ & $\begin{array}{l}2.08 * * \\
(1.16-3.72)\end{array}$ & $\begin{array}{l}0.95 \\
(0.52-1.72)\end{array}$ & $\begin{array}{l}3.02 * \\
(1.78-5.12)\end{array}$ & $\begin{array}{l}2.11 * * \\
(1.03-4.33)\end{array}$ \\
\hline
\end{tabular}

$* p<0.01, * * p<0.05$

a $95 \%$ confidence interval 


\section{Albuminuria by systolic blood pressure}

Type I diabetes prevalence $(\%)$

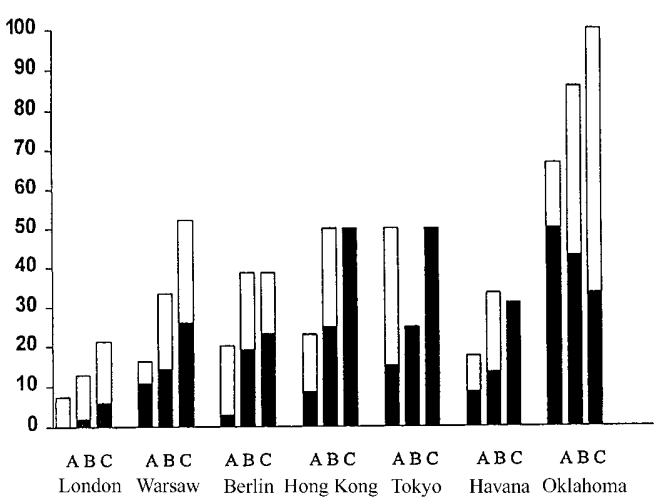

Fig.6. Prevalence (\%) of increased UAE by systolic blood pressure (A, <140; B, 140-159; C, > = $160 \mathrm{mmHg}$ ), type of diabetes and centre. $\square>=300 \mathrm{mg} / \mathrm{g} ; \square 30-299 \mathrm{mg} / \mathrm{g}$

\section{Discussion}

Wide variation in the prevalence of increased UAE was observed among the eight centres. In American

Fig. 7. Prevalence (\%) of increased UAE by smoking status (no, yes), type of diabetes and centre. $\mathbf{\square}>=300 \mathrm{mg} / \mathrm{g}$; $30-299 \mathrm{mg} / \mathrm{g}$
Type II diabetes

prevalence (\%)

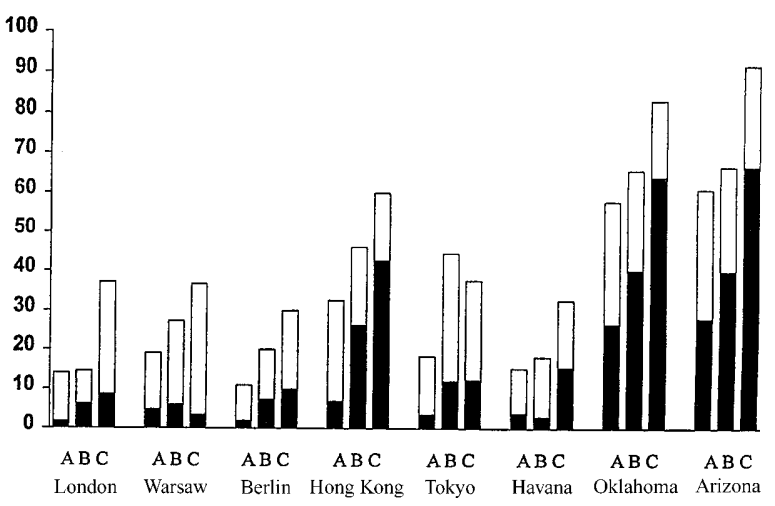

Indian patients it was more than twice the rate in Asian patients which, in turn, exceeded that in the European and Havana centres. Similar patterns were found in baseline proteinuria using precipitation methods $[21,22]$ and they are consistent with other reports of higher rates of diabetic nephropathy in Asians and American Indians [23, 24]. These differences were independent of the other risk factors included in the multivariate analyses so that variation in ethnic and/or genetic susceptibility to renal disease [25] could be contributing factors as could varying liability to non-diabetic causes of proteinuria. Our prevalence rates were estimated at follow-up after relatively long diabetes durations (15-23 years) and with varying survivorship among the eight centres [26].

\section{Albuminuria by current smoking status}

Type I diabetes prevalence (\%)
Type II diabetes

prevalence (\%)
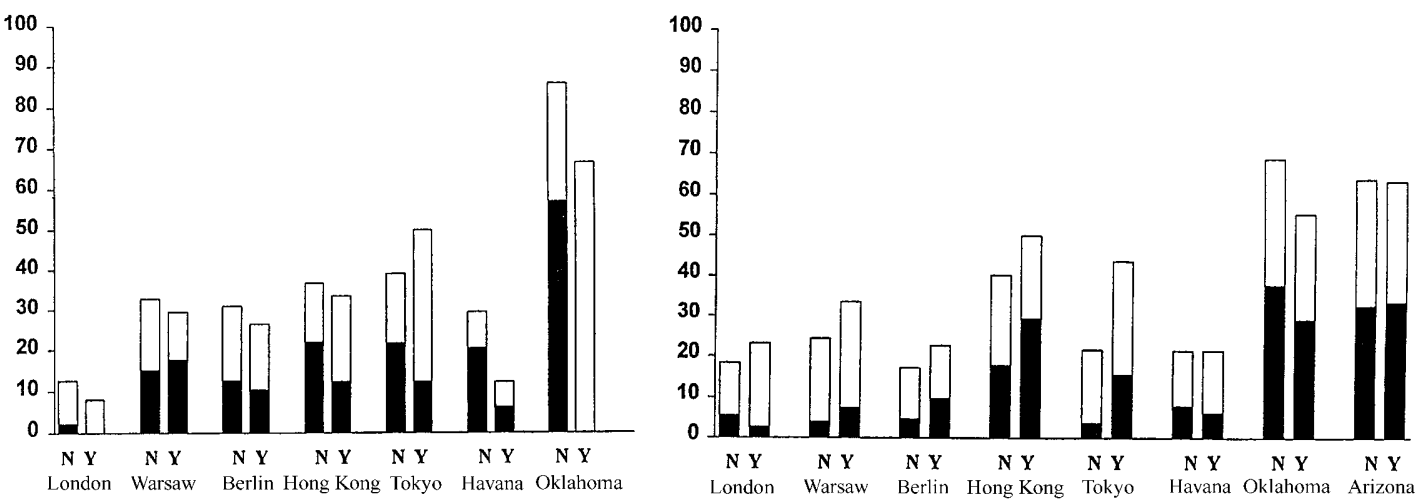
Table 4. Prevalence (\%) of vascular complications by urinary albumin excretion and centre. RR relative ratio $\geq 30 /<30$

\begin{tabular}{|c|c|c|c|c|c|c|c|c|c|c|c|c|}
\hline \multirow[b]{2}{*}{ Centre } & \multicolumn{3}{|c|}{ Coronary heart disease } & \multicolumn{3}{|l|}{ Stroke } & \multicolumn{3}{|c|}{ Lower-extremity amputation } & \multicolumn{3}{|c|}{ Retinopathy } \\
\hline & $<30 \mathrm{mg} / \mathrm{g}$ & $\geq 30 \mathrm{mg} / \mathrm{g}$ & $\mathrm{RR}$ & $<30 \mathrm{mg} / \mathrm{g}$ & $\geq 30 \mathrm{mg} / \mathrm{g}$ & RR & $<30 \mathrm{mg} / \mathrm{g}$ & $\geq 30 \mathrm{mg} / \mathrm{g}$ & RR & $<30 \mathrm{mg} / \mathrm{g}$ & $\geq 30 \mathrm{mg} / \mathrm{g}$ & RR \\
\hline London & 22.7 & 44.7 & $1.97 *$ & 2.5 & 8.0 & $3.20 * *$ & 0.7 & 0.0 & - & 57.2 & 77.6 & $1.36^{*}$ \\
\hline Warsaw & 29.3 & 32.1 & 1.10 & 1.5 & 3.8 & 2.51 & 5.3 & 9.4 & 1.77 & 37.9 & 53.9 & $1.42 * *$ \\
\hline Hong Kong & 16.3 & 34.9 & $2.14 *$ & 3.8 & 12.7 & $3.34 *$ & 0.0 & 2.7 & - & 65.8 & 76.2 & 1.16 \\
\hline Tokyo & 10.6 & 14.3 & 1.35 & 2.2 & 3.9 & 1.77 & 1.1 & 1.3 & 1.18 & 41.7 & 64.9 & $1.56^{*}$ \\
\hline Havana & 19.7 & 30.3 & 1.54 & 0.9 & 0.0 & - & 2.6 & 7.5 & 2.91 & 53.3 & 69.2 & $1.30 * *$ \\
\hline
\end{tabular}

$* \mathrm{p}<0.01, * * \mathrm{p}<0.05$

Table 5. Odds ratio (and $95 \% \mathrm{CI}$ ) of variables associated with increased albumin excretion (UAC ratio $\geq 30 \mathrm{vs}<30 \mathrm{mg} / \mathrm{g}$ ) from stepwise logistic regression by centre

\begin{tabular}{|c|c|c|c|c|c|c|c|c|}
\hline Variables & London & Warsaw & Berlin & Hong Kong & Tokyo & Havana & Oklahoma & Arizona \\
\hline $\begin{array}{l}\text { Sex } \\
(0 \text {-male, 1-female })\end{array}$ & $\begin{array}{l}0.46 \\
(0.22-0.95)^{\mathrm{a}}\end{array}$ & $\begin{array}{l}0.59 \\
(0.26-1.32)\end{array}$ & $\begin{array}{l}0.85 \\
(0.41-1.76)\end{array}$ & $\begin{array}{l}0.76 \\
(0.42-1.40)\end{array}$ & $\begin{array}{l}1.47 \\
(0.75-2.91)\end{array}$ & $\begin{array}{l}0.91 \\
(0.50-1.68)\end{array}$ & $\begin{array}{l}0.93 \\
(0.47-1.86)\end{array}$ & $\begin{array}{l}0.65 \\
(0.29-1.47)\end{array}$ \\
\hline $\begin{array}{l}\text { Type of diabetes } \\
\text { (0-Type II, 1-Type I) }\end{array}$ & $\begin{array}{l}0.39 \\
(0.14-1.11)\end{array}$ & $\begin{array}{l}0.64 \\
(0.23-1.76)\end{array}$ & $\begin{array}{l}0.67 \\
(0.23-1.92)\end{array}$ & $\begin{array}{l}0.59 \\
(0.29-1.24)\end{array}$ & $\begin{array}{l}1.28 \\
(0.51-3.23)\end{array}$ & $\begin{array}{l}1.26 \\
(0.47-3.44)\end{array}$ & $\begin{array}{l}1.40 \\
(0.24-8.31)\end{array}$ & $\begin{array}{l}- \\
-\end{array}$ \\
\hline $\begin{array}{l}\text { Age } \\
\text { (years) }\end{array}$ & $\begin{array}{l}1.04 \\
(0.97-1.11)\end{array}$ & $\begin{array}{l}0.96 \\
(0.90-1.03)\end{array}$ & $\begin{array}{l}0.99 \\
(0.93-1.06)\end{array}$ & $\begin{array}{l}1.02 \\
(0.97-1.07)\end{array}$ & $\begin{array}{l}0.97 \\
(0.92-1.02)\end{array}$ & $\begin{array}{l}1.02 \\
(0.97-1.08)\end{array}$ & $\begin{array}{l}1.04 \\
(0.98-1.10)\end{array}$ & $\begin{array}{l}1.02 \\
(0.96-1.08)\end{array}$ \\
\hline $\begin{array}{l}\text { Mean blood pressure } \\
\text { (per mmHg change) }\end{array}$ & $\begin{array}{l}1.02 \\
(1.00-1.05)\end{array}$ & $\begin{array}{l}1.04 * \\
(1.01-1.07)\end{array}$ & $\begin{array}{l}1.05^{*} \\
(1.02-1.08)\end{array}$ & $\begin{array}{l}1.04 * \\
(1.01-1.06)\end{array}$ & $\begin{array}{l}1.03 * \\
(1.01-1.06)\end{array}$ & $\begin{array}{l}1.03 * * \\
(1.01-1.05)\end{array}$ & $\begin{array}{l}1.03 * \\
(1.00-1.05)\end{array}$ & $\begin{array}{l}1.03 * \\
(1.00-1.07)\end{array}$ \\
\hline $\begin{array}{l}\text { BMI } \\
\text { (per } \mathrm{kg} / \mathrm{m}^{2} \text { quartile) }\end{array}$ & $\begin{array}{l}1.10^{*} \\
(1.01-1.20)\end{array}$ & $\begin{array}{l}1.13 * * \\
(1.04-1.23)\end{array}$ & $\begin{array}{l}1.05 \\
(0.95-1.16)\end{array}$ & $\begin{array}{l}0.96 \\
(0.89-1.04)\end{array}$ & $\begin{array}{l}1.08 \\
(0.96-1.22)\end{array}$ & $\begin{array}{l}0.95 \\
(0.90-1.02)\end{array}$ & $\begin{array}{l}1.01 \\
(0.95-1.07)\end{array}$ & $\begin{array}{l}1.00 \\
(0.94-1.08)\end{array}$ \\
\hline $\begin{array}{l}\text { Current smoking status } \\
\text { (0-no, } 1 \text {-yes })\end{array}$ & $\begin{array}{l}1.21 \\
(0.57-2.59)\end{array}$ & $\begin{array}{l}1.38 \\
(0.59-3.24)\end{array}$ & $\begin{array}{l}1.37 \\
(0.58-3.22)\end{array}$ & $\begin{array}{l}1.08 \\
(0.56-2.05)\end{array}$ & $\begin{array}{l}3.58 * \\
(1.76-7.26)\end{array}$ & $\begin{array}{l}0.94 \\
(0.51-1.77)\end{array}$ & $\begin{array}{l}0.57 \\
(0.28-1.16)\end{array}$ & $\begin{array}{l}0.86 \\
(0.35-2.11)\end{array}$ \\
\hline $\begin{array}{l}\text { Retinopathy } \\
\text { (0-no, 1-yes) }\end{array}$ & $\begin{array}{l}2.41 * * \\
(1.09-5.35)\end{array}$ & $\begin{array}{l}1.33 \\
(0.63-2.82)\end{array}$ & $\begin{array}{l}2.66^{*} \\
(1.03-6.85)\end{array}$ & $\begin{array}{l}1.10 \\
(0.58-2.09)\end{array}$ & $\begin{array}{l}1.81 * \\
(0.96-3.41)\end{array}$ & $\begin{array}{l}2.02 * * \\
(1.02-4.02)\end{array}$ & $\begin{array}{l}2.56^{*} \\
(1.22-5.35)\end{array}$ & $\begin{array}{l}1.23 \\
(0.60-2.53)\end{array}$ \\
\hline
\end{tabular}

$* p<0.01, * * p<0.05$

a95 \% confidence interval

Differences are not likely to have been produced by survival biases; in Arizona, Hong Kong, Tokyo, and Oklahoma higher renal disease mortality during the follow-up period has been reported [26].

In this study, UAE was clearly associated with the single baseline measurement of fasting glucose in the pooled subgroup in which the data were available. The relation with higher arterial pressures, observed at all centres, is well recognised [4, 13, 22-24, 27-30]. In Pima Indians, high blood pressure even before diabetes diagnosis predicts increased UAE during its course [31]. The development and progression of clinical nephropathy are accelerated by raised blood pressure. Their correction reduces UAE and delays progression to renal failure $[10,13,32,33]$. The relation with blood pressure is complex, however, because genetic markers of hypertension could also in- dicate susceptibility to the development of diabetic nephropathy [34]. The association of UAE with insulin use in Oklahoma, Hong Kong, and Tokyo, as reported by others $[29,35]$, probably reflects the effect of the severity of diabetes in terms of the degree of hyperglycaemia.

The association of abnormal UAE with higher prevalence of coronary heart disease, stroke and lower-extremity amputation is consistent with other reports $[4,5,27,36]$. The expected associations between increased UAE and diabetic retinopathy was present in all centres and consistent with previous observations $[4,22,26]$.

Much of the wide variation in the prevalence of abnormal UAE among the eight centres of this study has yet to be explained. An important contribution of glycaemic control was indicated by the predictive power 
Table 6. Odds ratio (and $95 \%$ CI) of variables associated with macroalbuminuria (UAC ratio $\geq 300 \mathrm{vs}<300 \mathrm{mg} / \mathrm{g}$ ) from stepwise logistic regression by centre

\begin{tabular}{|c|c|c|c|c|c|c|c|c|}
\hline Variables & London & Warsaw & Berlin & Hong Kong & Tokyo & Havana & Oklahoma & Arizona \\
\hline $\begin{array}{l}\text { Sex } \\
(0 \text {-men, 1-women })\end{array}$ & $\begin{array}{l}0.92 \\
(0.19-4.51)^{\mathrm{a}}\end{array}$ & $\begin{array}{l}0.94 \\
(0.27-3.21)\end{array}$ & $\begin{array}{l}0.88 \\
(0.29-2.68)\end{array}$ & $\begin{array}{l}1.66 \\
(0.77-3.61)\end{array}$ & $\begin{array}{l}1.50 \\
(0.43-5.22)\end{array}$ & $\begin{array}{l}1.40 \\
(0.55-3.59)\end{array}$ & $\begin{array}{l}1.03 \\
(0.55-1.94)\end{array}$ & $\begin{array}{l}0.80 \\
(0.33-1.91)\end{array}$ \\
\hline $\begin{array}{l}\text { Type of diabetes } \\
\text { (0-Type II, 1-Type I) }\end{array}$ & $\begin{array}{l}0.09 * \\
(0.01-0.78)\end{array}$ & $\begin{array}{l}2.38 \\
(0.48-11.7)\end{array}$ & $\begin{array}{l}0.70 \\
(0.15-3.27)\end{array}$ & $\begin{array}{l}0.69 \\
(0.27-1.76)\end{array}$ & $\begin{array}{l}1.62 \\
(0.46-5.69)\end{array}$ & $\begin{array}{l}1.51 \\
(0.39-5.84)\end{array}$ & $\begin{array}{l}0.86 \\
(0.21-3.53)\end{array}$ & - \\
\hline $\begin{array}{l}\text { Age } \\
\text { (years) }\end{array}$ & $\begin{array}{l}1.09 \\
(0.93-1.29)\end{array}$ & $\begin{array}{l}0.99 \\
(0.89-1.09)\end{array}$ & $\begin{array}{l}1.00 \\
(0.90-1.11)\end{array}$ & $\begin{array}{l}1.02 \\
(0.95-1.08)\end{array}$ & $\begin{array}{l}1.07 \\
(0.97-1.17)\end{array}$ & $\begin{array}{l}0.96 \\
(0.88-1.04)\end{array}$ & $\begin{array}{l}1.01 \\
(0.95-1.06)\end{array}$ & $\begin{array}{l}1.00 \\
(0.94-1.06)\end{array}$ \\
\hline $\begin{array}{l}\text { Mean blood pressure } \\
\text { (per mmHg change) }\end{array}$ & $\begin{array}{l}1.06^{*} \\
(1.00-1.12)\end{array}$ & $\begin{array}{l}1.04 * * \\
(1.00-1.09)\end{array}$ & $\begin{array}{l}1.07 * \\
(1.02-1.11)\end{array}$ & $\begin{array}{l}1.07 * \\
(1.04-1.10)\end{array}$ & $\begin{array}{l}1.05^{* *} \\
(1.00-1.10)\end{array}$ & $\begin{array}{l}1.04 * * \\
(1.01-1.07)\end{array}$ & $\begin{array}{l}1.01 \\
(0.99-1.04)\end{array}$ & $\begin{array}{l}1.03 * * \\
(1.00-1.06)\end{array}$ \\
\hline $\begin{array}{l}\text { BMI } \\
\text { (per } \mathrm{kg} / \mathrm{m}^{2} \text { quartile) }\end{array}$ & $\begin{array}{l}0.97 \\
(0.81-1.16)\end{array}$ & $\begin{array}{l}1.00 \\
(0.88-1.13)\end{array}$ & $\begin{array}{l}0.94 \\
(0.79-1.10)\end{array}$ & $\begin{array}{l}0.96 \\
(0.87-1.07)\end{array}$ & $\begin{array}{l}1.01 \\
(0.82-1.26)\end{array}$ & $\begin{array}{l}0.91 \\
(0.82-1.01)\end{array}$ & $\begin{array}{l}1.01 \\
(0.96-1.07)\end{array}$ & $\begin{array}{l}0.92^{* *} \\
(0.84-1.01)\end{array}$ \\
\hline $\begin{array}{l}\text { Current smoking status } \\
(0 \text {-no, } 1 \text {-yes })\end{array}$ & $\begin{array}{l}0.36 \\
(0.03-3.89)\end{array}$ & $\begin{array}{l}1.22 \\
(0.34-4.33)\end{array}$ & $\begin{array}{l}1.43 \\
(0.40-5.10)\end{array}$ & $\begin{array}{l}1.80 \\
(0.80-4.08)\end{array}$ & $\begin{array}{l}3.93 * * \\
(1.22-12.7)\end{array}$ & $\begin{array}{l}0.74 \\
(0.28-2.00)\end{array}$ & $\begin{array}{l}0.64 \\
(0.31-1.29)\end{array}$ & $\begin{array}{l}0.83 \\
(0.32-2.13)\end{array}$ \\
\hline $\begin{array}{l}\text { Retinopathy } \\
\text { (0-no, 1-yes) }\end{array}$ & $\begin{array}{l}3.55 \\
(0.35-35.8)\end{array}$ & $\begin{array}{l}1.60 \\
(0.53-4.83)\end{array}$ & $\begin{array}{l}6.46^{*} \\
(1.30-32.0)\end{array}$ & $\begin{array}{l}1.39 \\
(0.56-3.45)\end{array}$ & $\begin{array}{l}6.82^{*} \\
(1.41-33.0)\end{array}$ & $\begin{array}{l}2.07 \\
(0.67-6.42)\end{array}$ & $\begin{array}{l}2.86^{*} \\
(1.21-6.77)\end{array}$ & $\begin{array}{l}2.14 * * \\
(0.96-4.80)\end{array}$ \\
\hline
\end{tabular}

$* p<0.01, * p<0.05$

a95 \% confidence interval

of the single baseline fasting plasma glucose for incident macroalbuminuria at follow-up. This analysis was limited to a pooled group; therefore we cannot determine if poor glycaemic control had greater impact in one centre than another. The association of abnormal UAE with vascular disease was apparent in all centres, even in those like Tokyo and Arizona with relatively low risk of coronary heart disease and high prevalence of abnormal UAE. The associations of UAE with other risk factors were generally similar. Our findings are consistent with the contention that regional biological or genetic variation could also contribute to the susceptibility to nephropathy.

\section{References}

1. Eggers PW, Connerton R, McMullan M (1984) The Medicare experience with end-stage renal disease: trends in incidence, prevalence, and survival. Health Care Financ Rev 5: 69-88

2. US Renal Data System, USRDS 1999 Annual Data Report. National Institutes of Health, National Institute of Diabetes and Digestive and Kidney Diseases, Bethesda, MD, April 1999

3. Borch-Johnsen K, Kreiner S (1987) Proteinuria: value as predictor of cardiovascular mortality in insulin-dependent diabetes mellitus. BMJ 294: 1651-1654

4. Gall MA, Rossing P, Skott P et al. (1991) Prevalence of micro- and macroalbuminuria, arterial hypertension, retinopathy and large vessel disease in European Type II (non-insulin-dependent) diabetic patients. Diabetologia 34: 655-661

5. Mattock MB, Keen H, Viberti GC et al. (1988) Coronary heart disease and urinary albumin excretion rate in Type
II (non-insulin-dependent) diabetes patients. Diabetologia 31: $82-87$

6. Klein R, Klein BEK, Moss S, DeMets DL (1988) Proteinuria in diabetes. Arch Intern Med 148: 181-186

7. Viberti GC, Hill RD, Jarrett RJ, Argyropoulous A, Mahmud U Keen H (1982) Microalbuminuria as a predictor of clinical nephropathy in insulin-dependent diabetes mellitus. Lancet i: $1430-1432$

8. Mogensen CE (1984) Microalbuminuria predicts clinical proteinuria and early mortality in maturity-onset diabetes. N Engl J Med 310: 356-360

9. Nelson RG, Knowler WC, Pettitt DJ, Saad MF, Charles MA, Bennett PH (1991) Assessment of risk of overt nephropathy in diabetic patients from albumin excretion in untimed urine specimens. Arch Intern Med 151: 1761-1765

10. Marre M, Leblanc H, Suarez L, Guyenne T-T, Menard J, Passa P (1987) Converting enzyme inhibition and kidney function in normotensive diabetic patients with persistent microalbuminuria. BMJ 294: 1448-1452

11. Marre M, Chatellier G, Leblanc H, Guyene TT, Menard J, Passa P (1988) Prevention of diabetic nephropathy with enalapril in normotensive diabetics with microalbuminuria. BMJ 297: 1092-1095

12. Hommel E, Mathiesen E, Edsberg B, Bahnsen M, Parving $\mathrm{H}-\mathrm{H}$ (1986) Acute reduction of arterial blood pressure reduces urinary albumin excretion in type I (insulin-dependent) diabetic patients with incipient nephropathy. Diabetologia 29: 211-215

13. Parving H-H (1991) Impact of blood pressure and antihypertensive treatment on incipient and over nephropathy, retinopathy, and endothelial permeability in diabetes mellitus. Diabetes Care 14: 260-269

14. Jarrett RJ, Keen H, Grabauskas V (1979) The WHO Multinational Study of Vascular Disease in Diabetes. 1. General description. Diabetes Care 2: 175-186 
15. Lee ET, Keen H, Bennett PH, Fuller JH, Lu M, and the WHO Multinational Study Group (2001) Follow-up of the WHO Multinational Study of Vascular Disease in Diabetes: General description and morbidity. Diabetologia 44 [Supp 2]: S3-S13

16. Nathan DM, Rosenbaum C, Protasowicki VD (1987) Single-void urine samples can be used to estimate quantitative microalbuminuria. Diabetes Care 10: 414-418

17. Schwab SJ, Christensen RL, Dougherty K, Klahr S (1987) Quantitation of proteinuria by use of protein-to-creatinine ratios in single urine samples. Arch Intern Med 147: 943-944

18. SAS Institute Inc (1990) SAS Technical Report P-200, SAS/STAT Software, Version 6.04. Cary 1990

19. Mantel N, Haenszel W (1972) Statistical aspects of analysis of data from retrospective studies of disease. Journal of the Royal Statistical Society Stat Soc (B) 34: 187-220

20. Engelman L (1988) LR stepwise logistic regression. In: Dixon WJ (ed) BMDP statistical Software Manual. Vol. 2. Univ. of California Press, Berkeley, CA, p. 941-969

21. Diabetes Drafting Group (1985) Prevalence of small vessel and large vessel disease in diabetic patients from 14 centres. The World Health Organization Study of Vascular Disease in Diabetes. Diabetologia 28: 615-640

22. Jarrett RJ, Keen H (1979) The WHO Multinational Study of vascular disease in diabetes: 3. Microvascular disease. Diabetes Care 2: 196-201

23. Newman JM, Marfin AA, Eggers PW, Helgerson SD (1990) End state renal disease among Native Americans, 1983-86. Am J Public Health 80: 318-319

24. Samanta A, Burden AC, Feehally J, Walls J (1986) Diabetic renal disease: differences between Asian and white patients. BMJ 293: 366-367

25. Imperatore G, Hanson RL, Pettitt DJ, Kobes S, Bennett PH, Knowler WC (1998) Sib-pair linkage analysis for susceptibility genes for microvascular complications among Pima Indians with type 2 diabetes. Diabetes 47: 821-830

26. Head J, Fuller JH (1990) International variation in mortality among diabetic patients: the WHO Multinational Study of Vascular Disease in Diabetes. Diabetologia 33: 477-481
27. Klein R, Klein BEK, Linton KL, Moss SE (1992) Microalbuminuria in a population-based study of diabetes. Arch Intern Med 152: 153-158

28. Microalbuminuria Collaborative Study Group (1992) Microalbuminuria in type 1 diabetic patients. Diabetes Care 15: 495-501

29. Nelson RG, Kunzelman CL, Pettitt DJ, Saad MF, Bennett PH, Knowler WC (1989) Albuminuria in Type II (non-insulin-dependent) diabetes mellitus and impaired glucose tolerance in Pima Indians. Diabetologia 32: 870-876

30. Keen H, Chlouverakis C, Fuller JH, Jarrett RJ (1969) The concomitants of raised blood sugar: studies in newly-detected hyperglycaemics II. Urinary albumin excretion, blood pressure and their relation to blood sugar levels. Guys Hosp Rep 118: 247-254

31. Nelson RG, Pettitt DJ, Baird HR et al. (1993) Prediabetic blood pressure predicts urinary albumin excretion after the onset of Type II (non-insulin dependent) diabetes mellitus in Pima Indians. Diabetologia 36: 998-1001

32. Parving H-H, Hommel E (1988) High blood pressure is a major factors in progression of diabetic nephropathy. J Diabetes Complications; 2: 92-95

33. Christensen CK, Mogensen CE (1987) Antihypertensive treatment: long-term reversal of progression of albuminuria in incipient diabetic nephropathy: a longitudinal study of renal function. J Diabetes Complications 1: 45-52

34. Krolewski AS, Canessa M, Warram JH et al. (1988) Predisposition to hypertension and susceptibility to renal disease in insulin-dependent diabetes mellitus. N Engl J Med 318: 140-145

35. Andersen AR, Christiansen JS, Andersen JK, Kreiner S, Deckert T (1983) Diabetic nephropathy in Type I (insulindependent) diabetes: An epidemiological study. Diabetologia 25: 496-501

36. Allawi J, Jarrett RJ (1990) Microalbuminuria and cardiovascular risk factors in type 2 diabetes mellitus. Diabet Med 7: 115-118 